http://dx.doi.org/10.7197/1305-0028.46514

\title{
A rare location for an infrequent tumor: Plexiform neurofibroma in hepatic hilum
}

\section{Nadir bir tümör için nadir bir lokalizasyon: Hepatik hilumda Pleksiform nörofibroma}

\author{
*Mehmet Akif Türkoğlu ${ }^{1}$, Aslı Uçar ${ }^{2}$, Volkan Doğru' ${ }^{1}$, Güzide Ayşe Ocak ${ }^{3}$, Veli Vural ${ }^{1}$, Halil \\ Erbiş $^{1}$

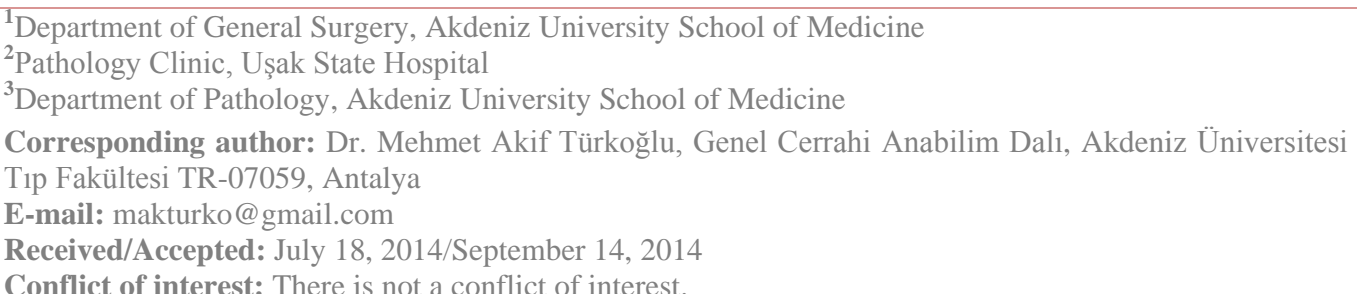

\section{SUMMARY}

Plexiform neurofibroma is frequently encountered in association with NF-1 but still can be seen as solitary lesions. While disease mostly involves extremities a very rare site of involvement is hepatic hilum. This paper reports a case of a 58 year old female patient with solitary plexiform neurofibroma located in the hepatoduodenal region which successfully treated by surgical procedure.

Keywords: Plexiform neurofibroma, neurofibromatosis, hepatic hilum

\section{ÖZET}

Pleksiform nörofibroma sıklıkla NF-1 ile birlikte karşılaşılan ancak soliter olarak ta gözlenebilen lezyonlardır. Hastalık genellikle ekstremiteleri ilgilendirirken hepatik hilum çok nadir bir tutulum bölgesidir. Bu yazı, cerrahi prosedür ile başarılı şekilde tedavi edilmiş, hepatoduodenal bölgede lokalize, pleksiform nörofibroma lezyonu olan 58 yaşındaki kadın bir vakayı sunmaktadır.

Anahtar sözcükler: Pleksiform nörofibroma, nörofibromatozis, hepatik hilum

\section{INTRODUCTION}

Neurofibromas are benign tumors of the peripheral nerves and may be localized, diffuse, or plexiform ${ }^{1}$. Plexiform neurofibroma (PN) considered pathognomonic for neurofibromatosis Type 1 (NF-1) is a benign tumoral disease which is characterised by nerve sheath involvement. Nevertheless, solitary plexiform neurofibroma independent of neurofibromatosis is also possible. Neck, pelvis and extremities are most frequent location, although numerous other sites are affected. Hepatic hilum lodgement is exceedingly uncommon as in our case . $^{2}$.

\section{CASE REPORT}

58 year old female patient with 2 year complaints of constent but mild right upper quadrant blunt abdominal pain increasing with meals was referred to our clinic with the diagnosis of intraabdominal enhancing round mass lesion, $2.5 \times 2.5 \mathrm{~cm}$ tumor at the interaortacaval space lying posterior to the portal vein and adjacent to superior mesenteric artery (SMA), vena cava inferior (VCI) and aorta was detected on dynamic computed tomography (CT). There was neither findings of other NF-1 components such as café-au-lait spots and cutaneous tumors nor relevant family history. At laparotomy, an elastic, wellrounded, sharply demarcated mass adherent to SMA, VCI and aorta was observed (Figure 1). Tumor was excised totally. Postoperative histopathological diagnosis was consistent with plexiform neurofibroma. Patient was successfully discharged 
from hospital with no postoperative complication. Microscopically, the lesion was composed of interlacing bundles of elongated cells with wavy nuclei and axons. (Figure 2). Immunohistopathologic assessment showed cells positive for S-100 and intratumoral axons stained positive for
NF (Figure 3). These findings were confirmed the diagnosis of benign plexiform neurofibroma. No evidence of malignant transformation was observed. As of this report, she had remained well with no recurrence during a follow-up period of one year.
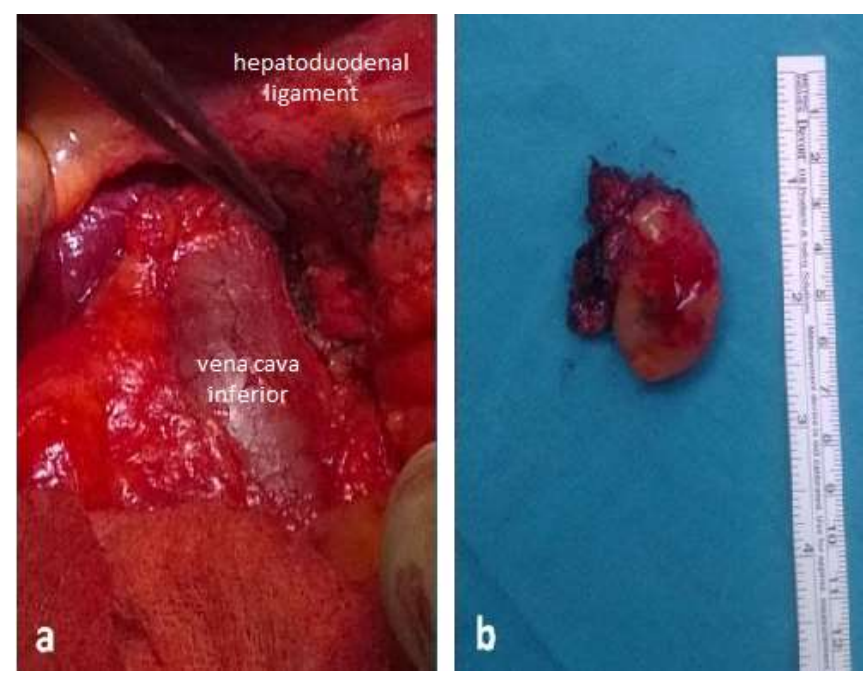

Figure 1: Space after removal of the mass adjacent to vascular structures while extending posterior to the hepatic hilum through the hepatoduodenal ligament (a), the mass (b).
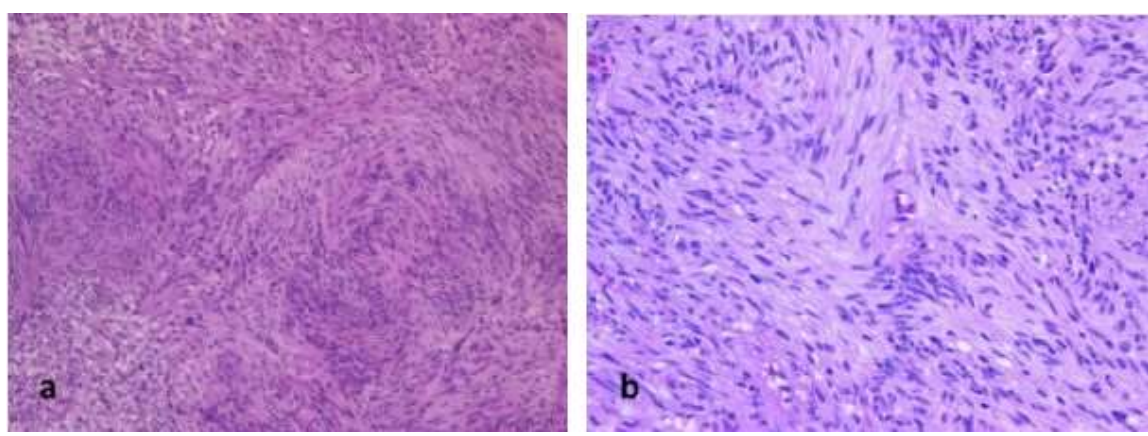

Figure 2: Interlacing bundles of elongated cells with wawy nuclei in the lesion (10x, $H \& E$ stain) (a). The elongated cells with wawy nuclei (20x, H\&E stain) (b).
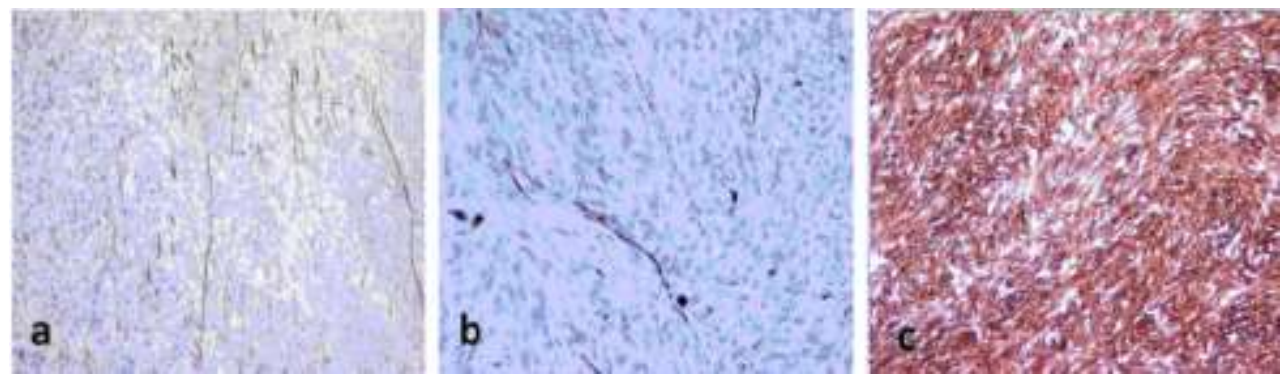

Figure 3: Intratumoral axons positive staining with NF (10X, NF stain) (a). Intratumoral axons positive staining with NF (20X, NF stain) (b). The Schwann cells of neurofibroma were positive for $S 100$ (20x, S-100 stain) (c). 


\section{DISCUSSION}

Plexiform neurofibroma is a benign nerve sheath tumor, which is considered pathognomonic of NF-1. Tumor won't turn malignant in time unless peripheral nerve sheath tumors develop over the lesion ${ }^{3}$. It consists of the same cell types as a cutaneous fibroma but has an expanded extracellular matrix, and its presence is one of the clinical criteria for the diagnosis of $\mathrm{NF}-1^{3}$. It may be present superficially or be located internally, and consists of proliferation of cells in the nerve sheath extending across the length of a nerve 4 . Plexiform neurofibroma were reported with a prevalence of $15-30 \%$ in patients with NF-1 $1^{5,6}$. However, PN is rarely recognized as a solitary lesion in a patient without features of NF-1in clinical practice ${ }^{7}$. Also Vincent et $\mathrm{al}^{8}$. in their study of 51 patients with plexiform neurofibroma reported that approximately $10 \%$ of the patients do not fulfill the National Institutes of Health Consensus Statement criteria for the diagnosis of NF-1. Thus the disease can be seen as solitary lesions. Typically, the most frequent involvement sites of plexiform neurofibroma in abdominopelvic region are abdominopelvic wall and the lumbosacral plexus and less frequently the retroperitoneum and pelvis all of which are extra-peritoneal involvements, although it's a rare presentation in terms of its location at the hepatic hilum ${ }^{2,9}$. Two previously published studies were reported for hepatic hilum involvement of PN but these are associated with NF-1 and not solitary le$\operatorname{sion}^{2,10}$. Therefore, extension of a plexiform neurofibroma involving the retroperitoneum and hepatoduodenal ligament into the hepatic hilum is an unusual manifestation. To our knowledge, this is the first report on the rare case of solitary $\mathrm{PN}$ without NF-1 in the hepatic hilum.

PN can persist for many years without causing clinical problems or may influence clinical presentation depending on the body system involved. They usually remain undetected until incidental detection by an imaging study or following the development of clinical symptoms. By compressing cranial nerves and/or peripheral nerve roots at the vertebral column PN can cause disfigurement, disability, and mortal- ity together with symptoms like paresthesia, paralysis, drooling, sleeplessness, respiratory and gastrointestinal distress, blindness, and loss of bowel and bladder control $^{11}$.

$\mathrm{PN}$ is characterized with tumoral enlargement in a long nerve segment with nodular components resulting in the gross pathologic appearance resembling "bag of worms"12,13. It is often difficult for a correct diagnosis to be made before surgical procedure because there are no characteristic clinical and laboratory findings, including tumor markers and imaging methods that distinguish PN from other neoplasms $^{14,15}$. Even if on CT, plexiform neurofibromas are visualized as multilobulated low-attenuation masses, no descriptive images were available ${ }^{16}$. Immunohistochemical study was demonstrated that all benign peripheral nerve sheath tumors were diffusely positive for S-100 protein, whereas malignant tumors were negative or focal positive17. We also detected S100 in specimens that exhibit benign nature of PN.

The standard treatment for neurofibromas has been surgical excision and the diagnosis can only be confirmed by histological examination. When patients have substantial clinical symptom or disfigurement, removal of the PN should be achieved in an attempt to alleviate the abdominal pain, although the tumor was deemed as difficult to remove in its entirety owing to its surrounding tissues extension ${ }^{2}$.

Although plexiform neurofibroma is frequently encountered in association with NF-1 it should be kept in mind that it can be in the form of solitary lesions as well. Hepatic hilum involvement in the disease remain asymptomatic as the disease slowly progress at this level. Thus diagnosing the lesion is difficult and if only when right upper quadrant pain arises. Dyspeptic symptoms such as early satiety and postprandial fullness may accompany this pain. Removal of the entire tumor, although always remain the main target in treatment strategy, preserving functionality of infiltrated tissues is the primary surgical prerequisite. 


\section{REFERENCES}

1. Coulon A, Milin S, Laban E, Debiais C, Jamet C, Goujon JM. Pathologic characteristics of the most frequent peripheral nerve tumors. Neurochirurgie 2009; 55: 454-8.

2. Hoshimoto S, Morise Z, Takeura C, Ikeda M, Kagawa T, Tanahashi Y, Okabe Y, Mizoguchi Y, Sugioka A. Plexiform neurofibroma in the hepatic hilum associated with neurofibromatosis Type 1: A case report. Rare Tumors 2009; 22: 1.

3. Theos A, Korf BR. Pathophysiology of neurofibromatosis Type 1 . Ann Intern Med 2006; 144: 842-9.

4. Korf BR. Plexiform neurofibromas. Am J Med Genet 1999; 89: 31-7.

5. Huson SM. The different forms of neurofibromatosis. Br Med J 1987; 294: 1113-4.

6. McGaughran JM, Harris DI, Donnai D. A clinical study of Type 1 neurofibromatosis in north west England. J Med Genet 1999; 36: 197-203.

7. Shi L, Liu FJ, Jia QH, Guan H, Lu ZJ. Solitary plexiform neurofibroma of the stomach: a case report.World J Gastroenterol 2014; 7: 5153-6.

8. Lin V, Daniel S, Forte V. Is a plexiform neurofibroma pathognomonic of neurofibromatosis type I? Laryngoscope 2004; 114: 1410-4.

9. Zacharia TT, Jaramillo D, Poussaint TY, Korf B. MR imaging of abdominopelvic involvement in neurofibromatosis Type 1: A review of 43 patients. Pediatr Radiol 2005; 35: 317-22.

10. Rodriguez E, Pombo F, Rodriguez I. Diffuse intrahepatic periportal plexiform neurofibroma. Eur J Radiol 1993; 16: 151-3.

11. Karl Staser, Feng-Chun Yang, and D Wade Clapp. Pathogenesis of plexiform neurofibroma: Tumorstromal/hematopoietic interactions in tumor progression. Annu Rev Pathol 2012; 7: 469-95.

12. Sehgal VN, Sharma S, Oberai R. Evaluation of plexiform neurofi- broma in neurofibromatosis Type 1 in 18 family members of 3 generations: Ultrasonography and magnetic resonance imaging a diagnostic supplement. Int J Dermatol 2009; 48: 275-9.

13. Pilavakia, D. Chourmouzib, A. Kiziridouc, A. Skordalakid, T. Zarampoukase, A. Drevelengasf. Imaging of peripheral nerve sheath tumors with pathologic correlation: Pictorial review. Eur JRadiol 2004; 52: 229-39.

14. Yano K, Okamura T, Yoshida Y. Mesenteric neurofibroma with von Recklinghausen's disease: A case report. Hepatogastroenterology 1998; 45: 456-8.

15. Imamoglu $M$, Cay A, Yariş $N$, Yayla S, Sarihan H. Intestinal mesenteric involvement with plexiform neurofibroma in neurofibromatosis Type 1. Pediatr Int 2006; 48: 337-9.

16. Lin J, Martel W. Cross-sectional imaging of peripheral nerve sheath tumors: Characteristic signs on CT, MR imaging, and sonography. Am J Roentgenol 2001; 176: 7582.

17. Ogose A, Hotta T, Morita T. Diagnosis of peripheral nevre sheath tumors around the pelvis. Jpn. J. Clin. Oncol 2004; 34: 405-13. 